\title{
Environmental Policy in the EU
}

Actors, Institutions and Processes

Edited by

Andrew Jordan and Viviane Gravey

Fourth edition published 2021

ISBN: 978-1-138-39214-4 (hbk)

ISBN: 978-1-138-39216-8 (pbk)

ISBN: 978-0-429-40233-3 (ebk)

\section{Chapter 19}

New policy dynamics in more uncertain times?

Viviane Gravey and Andrew Jordan

(CC BY-NC-ND 4.0)

DOI: $10.4324 / 9780429402333$ 


\title{
19 New policy dynamics in more uncertain times?
}

\author{
Viviane Gravey and Andrew Jordan
}

\section{Summary guide}

The dynamics of environmental policy making in the EU have always been in flux. After the heyday of relatively rapid policy development in the 1980s and 1990s, recent history has undoubtedly witnessed a sharp reduction in the number of new policy proposals and more criticism of existing rules and procedures. Are these new policy dynamics symptomatic of the growing maturity of the sector or an indication of declining political ambition? This chapter examines whether EU environmental policy is currently expanding, declining or staying broadly the same. It introduces different methods for measuring the direction and ambitiousness of policy change and applies them to specific examples of policy change. Finally, it discusses how and why two recent crises - the first economic (austerity) and the other political (Brexit) - have pushed environmental policy into more uncertain times which have challenged established dynamics in the sector. It concludes that while EU environmental policy has proven highly resilient to dismantling in the past, continuing political support for strong action in the future is not a given.

\section{Introduction}

The last two European Commissions (Barroso II, 2009-2014; Juncker 2014-2019) saw the environment move down the political agenda (Čavoški, 2015; Peterson, 2017). Barroso's second term focused on addressing the Eurozone crisis, while Juncker's term was built on a pledge to prioritise European 'added-value' in ten priority areas, only one of which had an environmental angle, and otherwise reduce the size of the EU's legislative programme (Bassot and Hiller, 2019). Conversely, the early days of the von der Leyen Commission witnessed environmental concern returning to the very top of the EU's agenda, with eye-catching plans for nothing less than a European Green Deal (see Chapters 12 and 16). But the heightened political status of environmental issues was very quickly undermined by the onset of the COVID-19 pandemic, which negatively impacted on the health of European citizens and pushed the Eurozone back into recession.

This chapter analyses how the dynamics of environmental policy making have adjusted to these more uncertain policy times. More specifically, it examines whether and to what extent EU policy is expanding, dismantling or staying broadly the same. Analysing policy dynamics over long periods of time is more difficult than first appears.

DOI: 10.4324/9780429402333-19 
For example, take the sharp fall in the number of new policy items adopted under the Juncker Commission. Did this imply that the EU had suddenly became less ambitious on environmental matters? Or did it indicate that the environmental acquis had become such 'a mature body of legislation' (Burns, Eckersley, and Tobin, 2019, p. 12) (see also Chapter 20), that there were no remaining policy gaps to fill - and that the main legislative task was to update existing policy items? Or perhaps the main political priority, as underlined in the three most recent Environmental Action Programmes, is not policy expansion for its own sake, but the implementation of existing policy (see Chapter 13).

In a famous essay in 1972, Anthony Downs posited that environmental policy the world over follows five main phases. He termed this the 'Issue Attention Cycle' whereby after a new policy problem has been detected and ambitious policy responses have had time to bed in, the mounting cost of implementation gradually reduces both public and government motivation to act (Downs, 1972). The last phase, the post-problem stage, he characterised as a 'twilight realm of lesser attention or spasmodic recurrences of interest' where public attention declines, although not as far down as the original level (Downs, 1972, p. 40).

Which stage is EU environmental policy currently at? As long ago as 2008, Wurzel argued it had moved past maturity, with the 1990s described as a period of 'sedate' policy development, although the 2000s showed signs of 'selective activism' specifically on climate change-related issues (Wurzel, 2008). If true, selective activism would arguably be marked by at least some policy expansion (i.e., the adoption of new policies and/or the updating of existing policies), albeit not across the board. But selective activism may also involve some dismantling, i.e., the cutting, removal or weakening of existing policies (Jordan, Bauer, and Green-Pedersen, 2013) in parallel to expansion. But selective activism is not the only alternative to maturity. We know from the US experience that 'maturity' can be followed by something very different - gridlock - where old, ambitious policies remain in place, often after efforts to dismantle them falter, and new problems are not addressed (due to insufficient cross-partisan support for new policies). With the higher (i.e., federal) level gridlocked, the onus falls on other, perhaps more local, levels of government and private actors to take up the slack (Sousa and Klyza, 2017; Vogel, 2003).

This chapter reviews the rapidly growing literature on long-term policy dynamics in the environmental sector, encompassing policy expansion, dismantling and/or stasis (Burns, Tobin, and Sewerin, 2019). The following section sets out the analytical indicators of change that academics have developed to measure the magnitude and direction of change since the early 1990s. The third section then reviews what might be driving the policy dynamics, especially any attempts at dismantling existing EU environmental policies. The fourth section applies these insights to make sense of the unfolding impact of two recent major events - namely, the post 2008 Eurozone crisis and Brexit on environmental policy dynamics. The final section concludes.

\section{Summary points}

- After 50 years of more or less steady policy expansion, in recent years, there has been a sharp fall in the adoption of new EU policies, in the context of multiple crises at EU level.

- For some, this fall indicates that the environmental acquis is mature and secure - and that the EU's focus should turn to improving implementation. 
For others, it shows the acquis is past its prime and/or should be reformed, and/or that EU lacks political ambition and should adopt new policies.

- In order to assess whether policy is expanding, contracting or staying broadly the same, this chapter analyses the historical dynamics of policy change and explores what drives EU political actors to support, or oppose, higher levels of environmental ambition.

\section{Capturing the dynamics of policy change}

The decline in the production of new environmental policy at EU level has been explained in the literature in three different ways. One explanation is that environmental policy has matured to the point where most environmental challenges are being addressed. Another is that the EU is still ambitious, but only selectively so. Thus, while some areas of environmental action have become more ambitious, others are being ignored and/or have become less ambitious. A third explanation is because of a growing polarisation of environmental politics, the EU has succumbed to political gridlock.

Exploring these different explanations requires us to delve into the basic nature of policy as well as the political context in which specific policies are debated and adopted. Howlett and Cashore (2009) distinguish between policy ends and policy means, which can each be subdivided in further sub-categories based on different levels of abstraction (from what are the general goals to what are the specific settings of policy instruments on the ground). Conversely, Bauer and Knill (2012) suggest two indicators: density (the number of policy instruments in a given policy area) and intensity (covering both ambition and scope, i.e., whether the policy instrument is narrowly or broadly targeted). This same typology of density and intensity can be itself further subdivided - hence, in their Index of Climate Policy Activity, Schaffrin, Sewerin, and Seubert (2014) break down intensity into six categories: policy integration, scope, targets, budget, implementation and monitoring. Most studies, however, have measured changes in density and intensity.

Building on these studies, the remainder of this section looks at the density and intensity (scope, ambition and budget) of EU environmental policy. While a mature acquis would imply limited changes in density and intensity, as well as limited political demands for policy change, gridlock is likely to be characterised by a failure to expand and/or dismantle policy. Finally, selective activism would see both expansion and dismantling being successful in different sub-areas of the environmental acquis.

\section{The density of policy}

A first step is to agree what the stock of environmental policy actually constitutes. After 50 years of steady policy expansion, this question is actually more difficult to answer than one may casually think. Formally, the acquis communautaire covers the Treaties, legislation adopted by European institutions, the evolving case law of the CJEU (see Chapter 7), political declarations adopted by the EU and any international agreements to which the EU is signatory (see Chapter 15). Searching through the EU legislation database, EUR-lex, yields over 1,000 binding legislative acts in the environmental area. This figure is already less than the whole acquis as it does not cover 

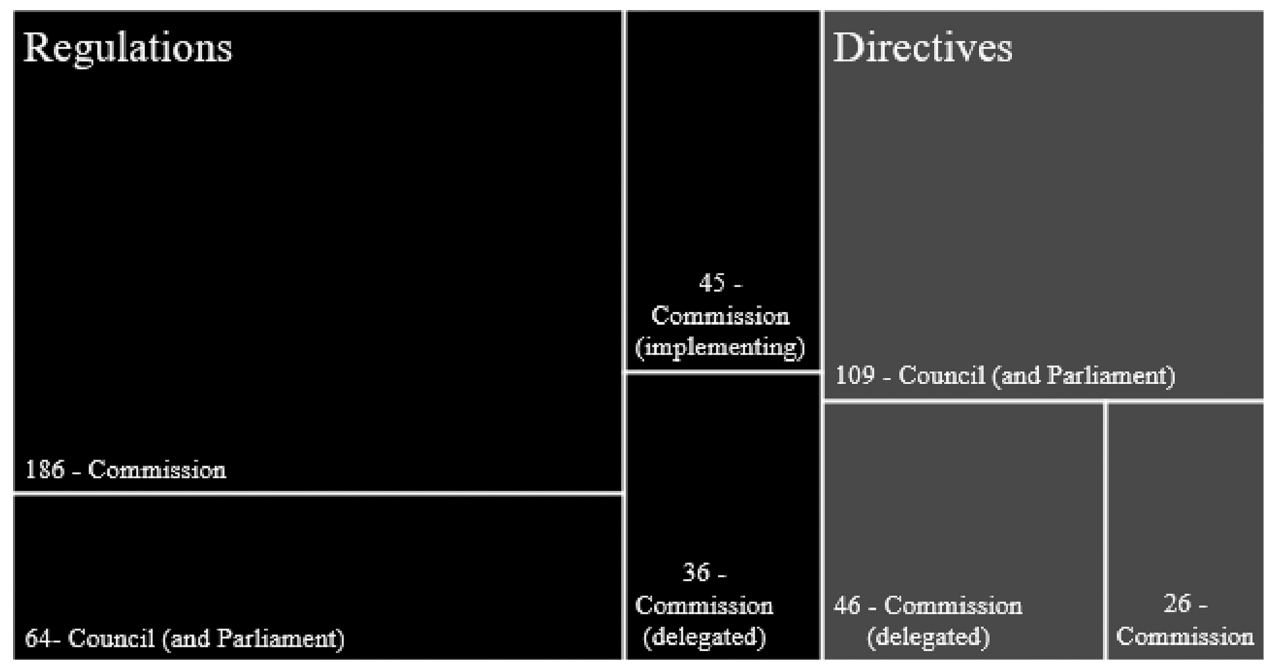

Figure 19.1 EU environmental policy in 2020 - legal types and responsible institutions.

Source: based on Eur-Lex.

international and EU Treaties, nor CJEU case law. Delreux and Happaerts (2016) approximate the acquis by measuring a subset of EU environmental legislation (only directives and regulations) and they find about 400 relevant texts in 2014. Searching EUR-lex for all environmental directives and regulations in force in 2020 (see Figure 19.1), we find 466 relevant legal texts. Critically, many of these either predate the use of the ordinary legislative procedure in environmental decision making (i.e., legislation adopted by the Council of the EU only) or cover implementation legislation produced by the European Commission (delegated and implementing acts) and adopted under different comitology procedures. This lower figure of 466 nicely illustrates the growing importance of delegated and implementing acts in the environmental sector (Burns and Tobin, 2020) (see also Chapters 6 and 8).

DG Environment equates the environmental acquis to an even smaller subset. In the context of enlargement negotiations, the acquis - understood as the rules that prospective member states need to integrate into their own legal orders before becoming members - is limited to a vague reference to 'over 200 pieces of EU environmental legislation' (DG Environment, 2020). Looking at Chapter 27 of the ongoing enlargement negotiations with the Western Balkan countries, we find less than 200 legal texts covering ten areas of environmental action (see Table 19.1).

Although the overall scale of EU environmental policy is open to discussion, the overall scope of EU environmental action is at least quite clear, ranging from noise pollution to industrial pollution control and action on climate change. But it also shows the limits of tracking environmental action solely by measuring the density of policy. Hence, in the environment enlargement chapter, the two largest bodies of legislation cover, on the one hand, waste, with 70 pieces of legislation, and, on the other hand, chemicals and GMOs with 47. Conversely nature protection only has nine pieces, and climate change eight. These large numbers do not of course imply that the EU 
Table 19.1 The contents of the EU's environment enlargement chapter

Categories of the EU environmental acquis

Number of legal instruments

Horizontal legislation 11

Air quality

25

Waste

70

Water quality

Nature protection

Industrial pollution control

9

Chemicals and GMOs

Climate change

Noise

Civil protection

TOTAL

Source: Adapted from Env.net.

considers waste issues to be any more important than say climate change, nature protection, water and air quality combined. Rather, these relatively large numbers also speak to the highly technical nature of these areas, covering a number of industries, sectors and business activities.

Armed with a measure of density, analysts can then start to measure the relative change in the acquis over time, where increases denote policy expansion and cuts indicate policy dismantling. But as Figure 19.2 shows, both can happen at the same time. For example, the replacement in 2008 of the 1996 Air Quality framework Directive (96/62/EC) and three out of four of its daughter directives with a new framework directive (2008/50/ EC) was a mixture of policy dismantling and expansion. Therefore, while measuring density furnishes important insights into policy change, it may actually tell us very little about changes in policy ambition. This is why measuring policy intensity is equally critical.

\section{The intensity of policy}

As with density, there are different ways to measure intensity (see Box 19.1), as well as different ways in which to measure changes in intensity (i.e., either relative or absolute

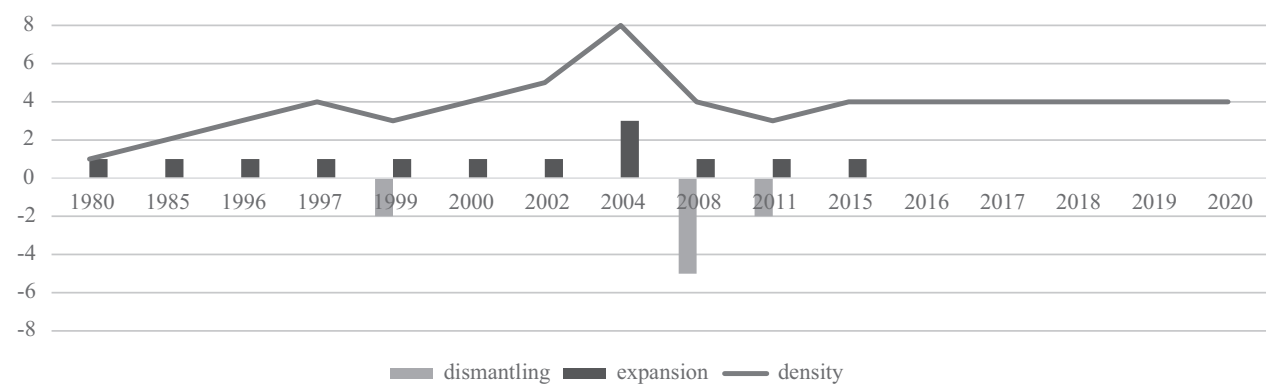

Figure 19.2 The density of EU air quality policy, 1980-2020.

Source: based on data from European Commission, 2020a 


\section{Box 19.1 Where next for EU air quality policy?}

How we define and measure policy dismantling has a direct impact on whether we find evidence of it or not. This issue, well known amongst social policy scholars as 'the dependent variable problem', has been discussed in recent accounts of environmental policy dismantling at EU level. Thus, when studying the level and scope of 20 air policy instruments, Steinebach and Knill (2017, p. 438) characterised the overall pattern of policy development between 1980 and 2014 as one of 'continuous policy expansion', with only very limited small-scale policy dismantling events in the early 2000s. Conversely, Gravey and Moore (2018) studied the policy ambition of four key EU directives addressing air quality issues and found a sharp fall of policy ambition after 2002 with respect to the Ambient Air Directive.

Yet, if we consider the methods used in these two analyses, the results are actually not contradictory. Thus, Steinebach and Knill found that overall, newer generations of EU policy instruments were more ambitious. But Gravey and Moore judged the EU's policy ambition against international standards, i.e., while the EU's policy had become more ambitious, it had failed to keep pace with World Health Organisation guidelines which became 'markedly more stringent due to new research on the health impacts of air pollution' (2018, p. 30). Sometimes, dismantling is only thought of as encompassing the active removal of legal protections from the acquis. But a failure to keep up with international standards is an example of another, more subtle form of dismantling - what Bauer and Knill (2012) term 'dismantling by default' (whereby policy settings are not adjusted upwards despite new scientific knowledge).

changes). Absolute measures use a scale of intensity against which each piece of policy is graded. A number of variations in this approach have been developed in the literature. For example, Burns and Carter (2010) developed a five-point typology measuring whether European Parliament amendments furthered or hindered greater ecological modernisation. This has since been updated to produce a five-point scoring table ranging from negative to high environmental ambition and applied to all stages of the legislative process, from the initial proposal to final legislation (Burns, Eckersleyet al., 2019). Alternatively, instead of ranking intensity as a whole, Schaffrin et al. (2014) proposed breaking down intensity into six different sub-indicators (integration, scope, targets, budget, implementation, monitoring) which are, in turn, graded 0 or 1 . The overall policy ranking using their Index of Policy Activity is made up of the sum of each of these indicators, allowing comparison between, for example, policies with a high dedicated budget and policies with a clear monitoring process. Conversely, relative rankings (see, e.g., Gravey and Jordan, 2016) track how new legislation compares to its predecessor - is it more or less ambitious? Is the budget allocated greater or smaller? Has the scope widened or narrowed? Both approaches have advantages and disadvantages. Absolute rankings provide an amalgamated grade (where, for example, increases in budget can offset decrease in implementation), while relative rankings can provide a finer-grained measure of the precise direction(s) of policy change that only really apply to quite mature bodies of policy. 
In summary, studying the dynamics of EU policy changes is still in its early days and methodological diversity is to be expected, and even welcome, as it allows analysts to capture better the complexity of policy change (although it can produce apparently puzzling results, see Box 19.1). But having measured policy change, we are still left with an even bigger puzzle: why do the policy actors introduced in Part II of this book seek to achieve expansion or dismantling at EU level?

\section{Summary points}

- There is a growing scholarly interest in the analysis of environmental policy change, including measuring its magnitude (minor or major change) and direction (expansion, stasis or dismantling).

- In practice, expansion, dismantling or stasis is not always clear-cut and can even occur simultaneously, greatly complicating the task of understanding long-term policy dynamics.

- When comparing the results of different studies, we need to be aware of their respective methodological choices.

\section{What drives policy change?}

Measuring policy change opens the door to more probing analyses of what ultimately drives policy dynamics at EU level. A useful starting point is to consider that each piece of the environmental acquis has a dual identity. First, it is a piece of policy, and as such, policy expansion and dismantling dynamics may differ from what exist in other policy areas such as social protection or health. Second, it is a piece of EU policy, and as such, policy expansion and dismantling dynamics may play out differently than at the member state level.

Table 19.2 Four typical criticisms of EU environmental policy

\begin{tabular}{|c|c|c|}
\hline & Critics of environmental action & $\begin{array}{l}\text { Proponent of greater } \\
\text { environmental action }\end{array}$ \\
\hline Europhile & $\begin{array}{l}\text { Actors in favour of continued European } \\
\text { integration who may be content } \\
\text { with current levels of environmental } \\
\text { ambition but who oppose } \\
\text { environmental expansion to } \\
\text { distract from other issues facing the } \\
\text { EU (i.e., migration, Brexit, economic } \\
\text { downturn) }\end{array}$ & $\begin{array}{l}\text { Actors who see the future of } \\
\text { European integration as a } \\
\text { 'green Europe', with strong } \\
\text { environmental ambition } \\
\text { and further environmental } \\
\text { integration reinforcing each } \\
\text { other's }\end{array}$ \\
\hline Eurosceptics & $\begin{array}{l}\text { Actors who oppose both environmental } \\
\text { actions irrespective of the level of } \\
\text { governance (for example, climate } \\
\text { sceptics) and European integration }\end{array}$ & $\begin{array}{l}\text { Actors who are opposed to the } \\
\text { EU and want either less, or } \\
\text { radically different form of } \\
\text { European integration but } \\
\text { support high environmental } \\
\text { ambition irrespective of the } \\
\text { level of governance }\end{array}$ \\
\hline
\end{tabular}


This duality further informs how EU-level actors engage in environmental policy making. Thus, different DGs of the European Commission will engage differently, as will the various political party groups in the European Parliament (see Chapters 6 and 7 for more details). Bringing these two characteristics (sector and level of governance) together allows us to draw an EU environmental policy discontent matrix (see Table 19.2) which differentiates between criticisms that focus on the policy (a specific piece of EU legislation, i.e., targeting the environmental dimension of EU environmental action) and those that focus on the polity (the EU, i.e., targeting the European dimension of EU environmental action).

Crucially, supporters of European integration and supporters of environmental action may not perfectly overlap (see Table 19.2). Thus, critics of EU environmental policy can be actors who:

- oppose both environmental action and European integration (e.g., the UK Independence Party is sceptical both of EU integration and climate change) (Reed, 2016).

- are wary of European integration but support environmental action at a more local or global level (e.g., La France Insoumise political party supports a profound ecological transition, but much less European integration).

- $\quad$ support continued European integration, but do not think environmental action should be a priority at EU level - e.g., the second Barroso Commission's decision to focus on addressing the Eurozone crisis at the cost of most other policy priorities (Gravey and Jordan, 2020).

- $\quad$ support continued European integration, but think that EU environmental action does not go far enough, e.g., many members of the Green 10 or the Greens/EFA MEPs (see Chapters 7 and 9).

The broader implication of Table 19.2 is that in order to understand policy dynamics at EU level, we need to draw both from the literature on environmental policy change, in particular dismantling, and on EU decision making.

\section{What drives policy dismantling?}

In his seminal work on policy dismantling, Paul Pierson argued that it is chiefly an exercise in blame avoidance (Pierson, 1994). While governments may be keen to cut public expenditure and social policy benefits, they will try to avoid being blamed by voters for doing so, e.g., blaming it on an external crisis or a different level of governance (such as the EU) or delaying the costs until well in the future (e.g., by building a long implementation phase into a given policy). Bauer and Knill (2012) used this basic insight as a starting point to consider environmental policy dynamics. Health and social policies typically produce diffuse costs - taxation is normally spread across the whole of society - but targeted benefits (focused on retired people, unemployed people, etc.), who can easily mobilise to oppose cuts and/or demand greater policy ambition. This is what drives the politics of dismantling in relation to Welfare State reform.

Conversely, environmental policies tend to produce concentrated costs - targeting specific industries or polluting activities - but diffuse benefits (broader society benefits from cleaner air and more biodiversity), making it more difficult to organise public support for policy expansion and/or against policy dismantling. Hence, environmental policy dismantling can be expected to be driven by credit claiming, not 
Table 19.3 Four policy dismantling strategies

\begin{tabular}{|c|c|c|}
\hline & Blame avoidance (low visibility) & Credit claiming (high visibility) \\
\hline \multirow{2}{*}{$\begin{array}{l}\text { Dismantling } \\
\quad \text { decision }\end{array}$} & Dismantling by arena-shifting & Active dismantling \\
\hline & $\begin{array}{l}\text { For example, delegating policy } \\
\text { responsibility to another agency or level } \\
\text { of governance without transferring } \\
\text { adequate funding. }\end{array}$ & $\begin{array}{l}\text { For example, agreeing new law } \\
\text { which reduces the scope, } \\
\text { level or density of policy }\end{array}$ \\
\hline \multirow{2}{*}{$\begin{array}{l}\text { No dismantling } \\
\text { decision }\end{array}$} & Dismantling by default & Symbolic dismantling \\
\hline & $\begin{array}{l}\text { For example, failing to update existing } \\
\text { legislation despite knowing it is outdated } \\
\text { or faulty }\end{array}$ & $\begin{array}{l}\text { For example, promising to } \\
\text { dismantle without following } \\
\text { through, e.g. commissioning } \\
\text { a report into cutting red tape }\end{array}$ \\
\hline
\end{tabular}

Source: Adapted from Bauer and Knill (2012).

blame avoidance. Politicians may find they can win support from key industries by cutting environmental protections without losing the support from voters, especially if they are distracted by other, more immediate issues such as jobs and the economy. From David Cameron's infamous 'get rid of all the green crap' comments (Carter and Clements, 2015) to the US Environmental Protection Agency's decision to suspend the enforcement of environmental laws during the COVID-19 pandemic (Milman and Holden, 2020) (see also Chapter 20), politicians frequently offer to relax environmental rules when industries ask for policy support.

Bauer and Knill (2012) identified four ideal types of policy dismantling strategy, based on either political action or inaction (see Table 19.3). Bauer et al. expected environmental policy dismantling to be pursued principally through either active or symbolic dismantling strategies, that is, for politicians to openly call for cutting or weakening environmental policy, but not always follow up these announcements with actions to deliver on them. Whether this hypothesis still holds in Europe, where environmental action has wide and growing popular support, is debatable (Burns, Tobin et al., 2019). We explore this question in the next section.

\section{What drives policy dismantling at EU level?}

In his work, Pierson (1994) compared two systems: the US and the UK. He found that it was comparatively easier to dismantle policies in a majoritarian system such as the UK, in which a Prime Minister with a large majority faces very few veto players, than in the US federal system which has a clear separation of powers and is thus riddled with veto points (see Chapter 11). Conversely, the high numbers of veto players in the US made it relatively easy to avoid blame for policy dismantling, whereas the UK government had nowhere to hide from voters. Building on this approach, Gravey and Jordan (2016) have argued that we can expect policy dismantling to be an uphill challenge in the 'hyperconsensual' EU system, in which policy change can only be achieved with intensive cooperation in and between the European Parliament and the Council (see Chapter 11 for further details). This means that in the EU, as in the US, it is much easier to block new legislation (i.e., stopping the flow of legislation) than unpicking and cutting existing rules (cutting the stock of legislation).

Existing explanations of the dynamics of EU environmental policy making - either noting maturity, selective ambition or gridlock (see Table 19.4) - start from a discussion 
Table 19.4 The dynamics of EU environmental policy making: three competing characterisations

\begin{tabular}{ll}
\hline Maturity & Current level of EU environmental action is broadly supported. \\
& Stasis prevails with limited expansion or dismantling. \\
& Environmental action is not a political priority, nor is it the focus \\
of political contestation \\
Both policy expansion and policy dismantling are attempted but fail. \\
Environmental acquis experiences stasis, even though the need \\
for environmental action becomes increasingly politicised and \\
divisive \\
Some parts of the environmental acquis experience expansion, \\
while others are ignored or dismantled. Political debates focus on \\
which areas of the acquis should be prioritised, and which can be \\
compromised to deliver on other political objectives
\end{tabular}

of policy density and of falling numbers of new environmental legislation. The Juncker Commission reduced new legislative activity back to the level of the early 2000s (see Figure 19.3), but the fall was not evenly shared. If we consider the ordinary legislative procedure files which involved the ENVI Committee in the European Parliament (thus covering both environment and health, see Chapter 8), we observe a marked reduction in its activity. Critically, the reduction predates Juncker: ENVI's activity as both a share of the European Parliament's activity and in absolute terms has fallen constantly since the late 1990s.

This reduction in new policies is surprising if we recall that one popular characterisation of the EU likens it to regulatory state (see Chapter 17). This gives the European Commission a strong vested interest in maintaining - and even expanding - the acquis.

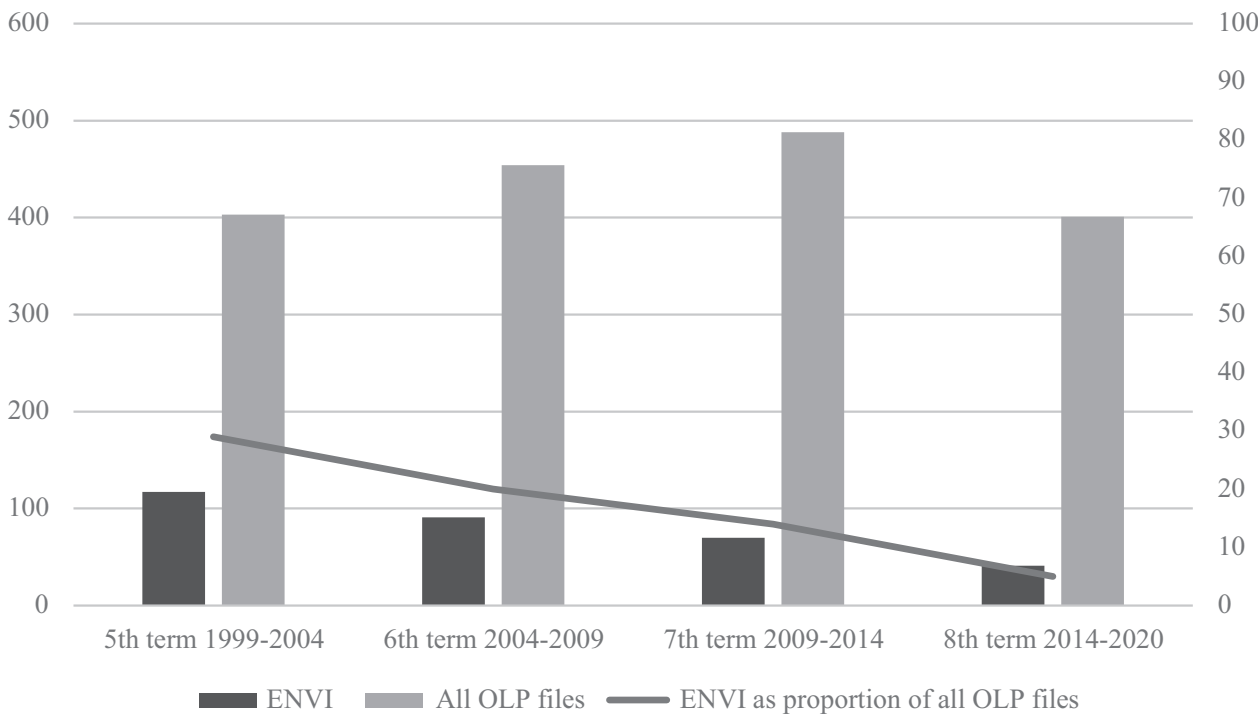

Figure 19.3 EU environmental policy: the fall in legislative output, 1999-2020.

Source: European Parliament Activity Reports 
Indeed, initial calls for dismantling in the 1990s were met with what can best be described as symbolic dismantling (see Table 19.3). Hence, the Commission, at the behest of member states such as the UK, France and Germany, created lists of policies to be revised and published reports on how EU legislation complied with the principles of subsidiarity and proportionality, but did not actually remove existing policies or even slow down the production of new ones (Gravey and Jordan, 2020).

But the picture started changing in the 2000s - calls for environmental policy dismantling not only came from outside the Commission but also from within, with a growing divide between DG Environment on the one hand and DG Competition (led by Commissioner Verheugen) on the other. Yet the Commission remained pro-policy expansion. Thus, writing in this period, Löfstedt (2007, p. 436) contended that if the Commission was serious about promoting Verheugen's agenda, Commission officials would soon be out of a job'. In recent years, the automatic assumption that the Commission will always support policy expansion and oppose dismantling has been further undermined. In their study of air and water policy dismantling from 1980 to 2014, Steinebach and Knill (2017) found that reduced policy ambition did not come from the legislators refusing to agree new policy proposals, but from the Commission failing to draft new proposals. In other words, far from being a policy entrepreneur advocating expansion at every opportunity, the European Commission had, they claimed, morphed into a stout defender of the status quo. In the face of increased popular awareness and scientific knowledge about the health impact of air and water pollution, its failure to produce new proposals was not, they argue, simply evidence of political stagnation. It is instead an example of dismantling by default, whereby insufficient or faulty policies were left unchanged. The central role played by the European Commission in EU decision making (see Chapter 6) renders EU environmental action particularly vulnerable to a form of selective activism whereby only some issues make it to the top of its political agenda.

\section{The pivotal role of the European Commission}

This shift in the European Commission's views can be explained in two complementary ways: by noting changes within its internal structures; and by exploring changes in the context in which it operates. Under Barroso and Juncker's leadership, the Commission went through a process of presidentialisation, with a reinforcement of the Secretariat General and Presidency's power over the policy DGs (Kassim, Connolly, Dehousse, Rozenberg and Bendjaballah, 2017). This took the form of greater use, first, of both impact assessments and ex post policy evaluations (see Chapter 14 for more details on both), and second, of political checks that every policy proposal put forward fitted with the political priorities of the Commission President. Such gatekeeping was exemplified by work done by the very first Vice-President of the European Commission, Frans Timmermans, in the Juncker Commission; all new policy proposals were carefully vetted by his team before being put to a vote in the College of Commissioners, thus opening the way for selective activism (Peterson, 2017).

The impact that presidentialisation had on the Commission's legislative agenda was crucially dependent on the President's personal political priorities, themselves heavily impacted by wider political context in Brussels. Critically, in his period in office, when the EU appeared to be in crisis, the Commission did not always call for 'more Europe'. He deemed that the Commission's role was to be the Guardian of the Treaties, not the 
Guardian of the acquis. Thus, dismantling policies is an option if it helps to sustain the overall European integration project. This pattern continued in the von der Leyen Commission, which pledged where necessary to 'cut EU red tape' (Gravey and Jordan, 2020).

This prioritisation of continued European integration over increasing environmental policy ambition can be detected in the Five Scenarios for a Future of Europe published by the Juncker Commission in 2017 (see Box 19.2). These paid scant attention to either environment or climate action.

While the Commission was careful not to favour any single scenario, Scenario 4, which sees the EU 'delivering more and faster in selected policy areas while doing less elsewhere' (European Commission, 2017, p. 22), directly echoed the Juncker Commission's pledge to be 'big on the big things and small on the small things'. It is noteworthy than in Scenario 4, environment and climate are not amongst the 'big' things the EU should focus on. And finally, considering the three different explanations of

\section{Box 19.2 Where next? Five possible EU futures}

In March 2017 the Juncker Commission published a White Paper setting out Five Scenarios for the Future of Europe. It commemorated the 60th anniversary of the Treaty of Rome and rejected a binary (i.e., more or less Europe) view of the future. The five scenarios were:

1 Carrying on:

The EU focuses on delivering its positive reform agenda.

2 Nothing but the Single Market:

The EU is gradually re-centred on the Single Market.

3 Those who want more, do more:

The EU allows willing member states to do more together in specific areas.

4 Doing less more efficiently:

The EU focuses on delivering more and faster in selected policy areas while doing less in others.

5 Doing much more together

The EU decides to do much more together across all policy areas.

These scenarios offer different possibilities with regards to policy expansion and dismantling. Scenario 4 would, for example, see both take place; Scenario 2 would see extensive dismantling of 'non-essential' policies; and Scenarios 3 and 5 would see expansion, though only for some member states. Scenario 2 in particular would threaten the EU environmental acquis with a 'strong focus on reducing regulation at EU level', leading to increasing differences in environmental standards across the EU, accompanied by the EU being 'no longer represented' in international negotiations on issues such as climate change. In Scenario 4, the environment is presented as an area for less, not more, action, with a move away 'from detailed harmonization towards a strict minimum'. The EU's Climate Leadership is excluded from all but Scenarios 5 and 1. These scenarios were indicative of the Juncker Commission priorities and are not binding on its successor. 
EU environmental policy dynamics (see Table 19.4), the Five Scenarios correspond to 'maturity' where most, if not all, political ambition is reserved for non-environmental matters.

\section{Summary points}

- EU environmental policies have been be challenged on many grounds, including their 'Europeaness' and their environmental ambition.

- The diffuse benefits and concentrated costs that are often generated by environmental policy actions may lead politicians to try to claim political credit amongst critics by pledging to dismantle green rules.

- Nevertheless, actually dismantling EU policies has often been a slow, uphill battle given the need to achieve consensus amongst myriad of actors, including the European Commission which is a pivotal actor.

- Recent developments have nevertheless demonstrated that the European Commission has a more ambivalent attitude to dismantling the environmental acquis than has historically been the case.

\section{EU environmental policy-making in times of crisis}

As the EU wrestles with the Coronavirus pandemic and its unfolding economic consequences, what will this crisis mean for environmental action? Will we see a green recovery, with a strong European Green Deal? Will we instead see different member states pulling the EU apart? Or will we see a recovery focused on narrow economic indicators? While it is too early to reach firm conclusions, we can learn from the EU experience in handling two recent crises: the post-2008 economic and financial crisis and the political crisis of Brexit. This section reviews research on them both in the light of our three competing characterisations of policy change (see Table 19.4) - namely, maturity, selective activism and gridlock - building on our understanding of the criticisms commonly levelled at EU environmental policy.

\section{Economic austerity}

While the economic crisis did not originate in Europe, it had long-lasting impact on the economic health and welfare of many countries in and outside the EU in the decade following 2008. When considering its impact, we need to distinguish between the flow of new legislation and the stock of environmental policy, i.e., the acquis. Starting with the flow, in response to the crisis, the Commission decided to prioritise policies that were strictly targeted at addressing the economic crisis and/or lessening its impact (Knill, Steinebach, and Fernández-i-Marín, 2020). This became clear under the second Barroso Commission (2009-2014) during which new policies aimed at cutting plastic waste was delayed (ENDS Europe, 2013). This stance was reaffirmed at the start of the next (i.e., Juncker) Commission (2014-2019) which pledged to focus on 'the "big things" like jobs and growth', and not 'present proposals that do not contribute to 
these priorities' (European Commission, 2014, p. 2). Comparing policy proposals tabled by the two Barroso Commissions, Burns, Eckersley et al. (2019, p. 3) found a clear 'crisis effect' characterised by a decline in the amount of EU environmental legislation brought forward and in the ambition of 'new legislation'. However, not all sub-sectors of environmental policy making were affected in the same ways; while there were fewer environmental policy proposals overall in Barroso's second term, the number of climate proposals rose sharply. Similarly, Gravey and Moore (2019) found that while 'old' policy areas such as air quality stagnated or even experienced dismantling (see Box 19.1), climate policy increased in both density and ambition. Beyond climate change, another rare example of selective activism was the adoption of a new regulation on invasive species in 2014 (Justo-Hanani and Dayan, 2020).

However, as noted above, selective activism can in principle entail both limited expansion and dismantling. In other words, while limited expansion may well describe environmental action through the legislative process, a different picture may emerge in the post-legislative process, which in the EU corresponds to comitology (see Chapter 6 for details). This is broadly what happened after 2008. So, while during the legislative process, both the Council and Parliament voted to increase the ambition of some of the Commission's proposals (Burns, Eckersley et al., 2019), in the post-legislative process, the Commission 'hidden away from legislative procedures' was able to weaken environmental policy ambitions (Pollex and Lenschow, 2020, p. 32). Pollex and Lenschow's main finding - that dismantling happens 'through the back door' of delegated and implementing acts in the field of sustainable consumption - was confirmed by the work of Burns and Tobin (2020, p. 13), who found that 'comitology policies were less ambitious on average during the crisis era'.

Considering both the reduced flow of new legislation and the drop in infringement action against member states failing to implement the environmental acquis (on this, see also Chapter 13), Knill et al. (2020, p. 375) argued that 'the Commission has clearly given up its former role as an environmental policy entrepreneur'. This was also evident in the Commission's attitude to the stock of environmental policy - both Barroso II and Juncker Commissions increasingly engaged with existing environmental legislation through the prism of cutting regulatory burdens and costs, not increasing ambition (Gravey and Jordan, 2020).

Finally, analyses of the impact of the crisis on EU environmental policy also need to consider the interplay between EU and national policies. Comparing the direction of environmental policy change in EU and non-EU countries, Burns, Tobin et al. (2019) found that 'the EU can act as a safeguard against policy dismantling and insulate against changes in government', but such 'safeguarding' is far from universal as EU-supported austerity policies in Greece profoundly undermined Greece's ability to implement and apply EU environmental policies (Lekakis and Kousis, 2013). Thus, EU environmental policy in the aftermath of the crisis is best characterised as exhibiting bursts of selective activism but longer periods of dismantling via the back door of comitology.

\section{Brexit and its aftermath}

The UK's withdrawal from the EU occurred via three sets of negotiations: the renegotiation of the UK's membership prior to the 2016 referendum; the 2016-2019 withdrawal negotiations; and the post-2019 negotiation of the future relationship. All three 
had an environmental dimension. As Chapter 5 argued, member states can be both leaders and laggards in different areas of environmental policy at the same or even different times. Prior to Brexit, the UK hindered EU policy expansion in some areas (fracking, soil, air quality) but supported it in others (climate change, the greening of the CAP and fisheries policy) (Hilson, 2018). Beyond specific policy areas, the UK was, however, often in the vanguard of a group of member states criticising the environmental acquis on the grounds of both subsidiarity (arguing certain environmental issues, such as soil protection and carbon taxation, were best dealt with by member states directly) and proportionality (arguing EU rules were placing unnecessary burdens on private actors).

As such, it came as no great surprise that the EU's regulatory powers were criticised in the period prior to the 2016 EU referendum (Gravey and Jordan, 2020). The then UK Prime Minister, David Cameron, negotiated a New Settlement with the EU, seeking concessions in four main areas (economic governance, competitiveness, sovereignty and immigration) which he hoped to use to convince UK voters to remain in the EU. On competitiveness, he demanded a review of the entire acquis to check whether it complied with subsidiarity and proportionality, as well as an agreement by the Commission to work on establishing specific regulatory burden reduction targets (Poptcheva and Eatock, 2016), which critics had long suspected would weaken existing environmental policies (Gravey and Jordan, 2020). Both points were included in a draft European Commission declaration as part of the New Settlement. But the UK voted to leave, precipitating a massive crisis in UK and EU politics.

During the first few months of the von der Leyen Commission, the EU appeared intent on continuing on the same path with or without the UK. Her Commission was not bound by David Cameron's New Settlement, yet still decided to deliver on one of the new settlement promise (specific regulatory burden reduction targets) by phasing in a 'one in, one out' policy, whereby 'every legislative proposal creating new burdens should relieve people and businesses of an equivalent existing burden at EU level in the same policy area' (European Commission, 2019b). This raised concerns amongst environmental NGOs in Brussels, who felt it was 'incompatible' with the EU's pledge to increase its climate efforts (Green10, 2019).

However, maintaining existing EU environment standards quickly rose to prominence once Brexit negotiations got underway (covering the UK's withdrawal from the EU and its future relationship with the EU). So-called level-playing field provisions emerged as a particularly contentious point, particularly given that the EU had by that point, committed to adopt and implement an ambitious package of new legislation contained in the European Green Deal. The EU wished to lock the UK into existing EU environmental protections mechanisms, whereas the UK preferred a looser arrangement whilst still preserving tariff- and quota-free access to the EU's single market.

After protracted negotiations on the withdrawal, the two sides were only able to bridge their differences by adopting, in late 2019, a non-binding Political Declaration (European Commission, 2019a), which outlined the commitments, both legal and political, that could eventually inform the wording of a subsequent treaty specifying the future trading relationship between them (Jordan, Gravey, Moore, and Reid, 2020). As Box 19.3 reveals, the Political Declaration recognised the strong environmental dimension of the playing field between the two sides. As Chapters 2 and 3 explained, EU environmental policies had originally developed to underpin the EU's Single Market, arguably creating the world's largest and most sophisticated level-playing field. 


\section{Box 19.3 Brexit and the environment: the 2019 Political Declaration}

XIV. LEVEL PLAYING FIELD FOR OPEN AND FAIR COMPETITION

77. Given the Union and the United Kingdom's geographic proximity and economic interdependence, the future relationship must ensure open and fair competition, encompassing robust commitments to ensure a level playing field. The precise nature of commitments should be commensurate with the scope and depth of the future relationship and the economic connectedness of the Parties. These commitments should prevent distortions of trade and unfair competitive advantages. To that end, the Parties should uphold the common high standards applicable in the Union and the United Kingdom at the end of the transition period in the areas of state aid, competition, social and employment standards, environment, climate change, and relevant tax matters. The Parties should in particular maintain a robust and comprehensive framework for competition and state aid control that prevents undue distortion of trade and competition; commit to the principles of good governance in the area of taxation and to the curbing of harmful tax practices; and maintain environmental, social and employment standards at the current high levels provided by the existing common standards. In so doing, they should rely on appropriate and relevant Union and international standards, and include appropriate mechanisms to ensure effective implementation domestically, enforcement and dispute settlement. The future relationship should also promote adherence to and effective implementation of relevant internationally agreed principles and rules in these domains, including the Paris Agreement.

(European Commission, 2019a)

Once the Declaration had been struck, negotiators moved on to discuss what form the new level playing field should take, at which point the interlinking of environmental ambition and fair competition re-emerged as key sticking points in the negotiations, alongside state-aid rules and fisheries - a somewhat ironic turn of events as the environment was only a footnote in Cameron's New Settlement and was barely mentioned at all during the highly emotive 2016 EU referendum campaign. The EU's insistence on the need for common environmental rules was formalised when it published its formal negotiating mandate, which not only called for a form of environmental policy stasis (or, to quote the jargon, 'dynamic alignment' between the two parties), but a commitment to further policy expansion:

the envisaged agreement should uphold the common high standards in the areas of State aid, competition, state-owned enterprises, social and employment standards, environmental standards, climate change, and relevant tax matters (...) the envisaged partnership should commit the Parties to continue improving their respective levels of protection with the goal of ensuring high levels of protection [in these areas].

(European Commission, 2020b) (emphasis added). 
This demand went well beyond what Boris Johnson's UK government wanted - a standard, free trade agreement in which both sides enjoyed full regulatory autonomy (Jordan et al., 2020).

In summary, both crises exhibited elements of environmental neglect (stasis and dismantling attempts characterised both the non-climate parts of the acquis during the economic crisis and the UK's New Settlement) and ambition (continued climate policy expansion during the economic crisis, strong commitment to an environmental levelplaying field in Brexit negotiations). Both confirmed that the EU can be somewhat hypocritical in both supporting and undermining its environmental ambitions to suit its political priorities (Knill et al., 2018). Thus, the Commission - the EU institution which seemed prepared to loosen environmental protections during the economic crisis - subsequently sought to monitor in fine detail the maintenance of environmental policy and governance protections within the UK to ensure that they did not regress after Brexit. The UK, perhaps understandably, argued that no other EU trade agreement attempted to bind another trading partner so closely to the environmental acquis, while the EU emphasised that the UK's economic size and geographical proximity meant that it was unreasonable to treat it as a conventional trading partner (Box 19.3).

\section{Summary points}

- Austerity at EU and national levels revealed the fragility of the EU environmental policy ambitions, which appeared to narrow down to climate change and reviewing and possibly updating existing legislation.

- The exogenous shock of Brexit witnessed a renewed commitment by the EU to maintain a level-playing field with the UK, built on both parties maintaining high environmental standards.

- Both crises usefully revealed that the EU's political support for environmental protection is actually quite variable; at times, it veered between downplaying the need for new policy protections and then suddenly advocating them.

\section{Conclusions}

After decades of almost uninterrupted legal constitutionalisation and policy expansion, EU environmental policy finds itself challenged by the same crises that engulfed other areas of European integration - the global financial crisis, Brexit, which saw a member state leave the EU for the first time, and COVID-19 to name just three. In order to understand how they have impacted EU environmental action, this chapter has reviewed the rapidly growing literature on broader EU policy dynamics, investigating three competing explanations: maturity, gridlock and selective activism.

It reviewed the different methods for understanding policy dynamics, encompassing, amongst other things, different tools for measuring policy density (the number of policies or policy instruments) and policy intensity (the scope and ambition of policy). It then investigated whether, over time, these two indicators have increased (policy expansion), decreased (policy dismantling) or stayed the same (policy stasis). It revealed 
that over the last 50 years, the environmental acquis has not steadily expanded and become ambitious over time - a story that dominated early academic accounts of EU environmental policy (see Chapter 4 for details). In fact, the overall picture has been long, more complicated and hence difficult to interpret; dismantling, expansion and stasis have occurred at the same time and even within the same policy instrument. However, clear and unambiguous examples of policy dismantling have been conspicuously rare over the last 50 years, with EU environmental policy characterised mainly by a mix of stasis and limited expansion. These findings offer stronger support to the 'selective activism' explanation outlined above.

Alongside tools to measure what is happening to policy, recent research has also sought to explain why changes have happened. This chapter identified four ideal types of criticism that are repeatedly levelled at EU environmental action. The ideal types highlighted how critics can be organised alongside not one, but two cleavages (pro/anti-European integration and pro/anti-environmental action). It further discussed how the consensual nature of EU decision-making systems actively hinders dismantling, although the European Commission is nonetheless a critical actor. When it shifts position, it alters the flow of new legislation.

Finally, it investigated the impact of both Brexit and the global financial crisis on EU environmental action. It showed how, in both cases, selective activism had eventually prevailed, albeit with some 'back door' dismantling through post-legislative (or comitology) instruments (what Chapter 11 discusses as transnational decision-making processes) together with a narrowing down in the focus of environmental ambition to more climate mitigation-related issues. Critically, recent research on both crises has confirmed that the European Commission is not an environmental policy entrepreneur by default; instead, it pursues further environmental ambition when it is aligned with its broader political agenda, thus confirming that the current dynamics of EU environmental policy are those of 'selective activism'. Thus, while the very recent burst of environmental ambition that bore the European Green Deal was welcomed by environmental NGOs, it was narrower in scope (mostly about climate, not environmental issues more broadly) than previous periods of environmental activism. Time will tell whether the levels of political commitment required to put it fully into practice are maintained across the EU institutions and all 27 member states.

\section{Summary points}

- When describing and explaining the long-term dynamics of EU environmental action, we need to be able to measure the magnitude and direction of policy change.

- Support for and opposition to environmental action at EU level can be understood as varying along two dimensions: the Europeanness (or otherwise) of the EU and whether it is pro (or anti) environmental protection.

- The EU's continued environmental ambition is not a given; recent dynamics have revealed fluctuating levels of support even within the European Commission. 


\section{Key questions}

1 Why has measuring policy change proven so difficult? Illustrate your answer with examples drawn from the existing academic literature.

2 Over the last ten years or so, has EU environmental policy expanded, contracted or stayed the same?

3 To what extent and why do you agree with the claim that the EU should focus more of its political energies on implementing and updating existing policies, as opposed to developing new ones?

4 In your view, which crisis event is likely to have the most long-lasting impact on EU policy-making dynamics: austerity, Brexit or COVID-19?

\section{Guide to further reading}

- Burns et al. (2019) offer a detailed account of how the 2008 economic crisis impacted environmental policy ambition in Europe, both at EU level and in its member states.

- A special issue of the journal Environmental Politics (Volume 28, 2019, Issue 2) entitled 'The Future of EU Environmental Politics and Policy' offers a comprehensive overview of recent academic work.

- Bauer and Knill (2012) summarise the existing literature on welfare state dismantling and apply it to a number of cases of policy dismantling in the social and environmental policy fields in the US and Europe.

\section{Online resources}

- European Commission: Better Regulation, why and how: https://ec.europa.eu/ info/law/law-making-process/planning-and-proposing-law/better-regulationwhy-and-how_en

- Corporate Europe Observatory: 'Better Regulation': corporate-friendly deregulation in disguise? https://corporateeurope.org/en/power-lobbies/2016/06/ better-regulation-corporate-friendly-deregulation-disguise

- Brexit and Environment: A network of academics analysing the impact of Brexit on the environment: https://www.brexitenvironment.co.uk/

\section{References}

Bassot, É., and Hiller, W. (2019). The Juncker Commission's Ten Priorities: An End-of-term Assessment. Brussels: European Parliament.

Bauer, M. W., and Knill, C. (2012). Understanding policy dismantling: An analytical framework. In M. W. Bauer, A. Jordan, C. Green-Pedersen, and A. Héritier (Eds.), Dismantling Public Policy (pp. 30-51). Oxford: Oxford University Press. 
Burns, C., and Carter, N. (2010). Is co-decision good for the environment? An analysis of the European Parliament's green credentials. Political Studies, 58(1), 123-142.

Burns, C., Eckersley, P., and Tobin, P. (2019). EU environmental policy in times of crisis. Journal of European Public Policy, 1763, 1-19.

Burns, C., and Tobin, P. (2020). Crisis, climate change and comitology: Policy dismantling via the backdoor? Journal of Common Market Studies, 1-18.

Burns, C., Tobin, P., and Sewerin, S. (Eds.). (2019). The Impact of the Economic Crisis on European Environmental Policy. Oxford: Oxford University Press.

Carter, N., and Clements, B. (2015). From "greenest government ever" to "get rid of all the green crap": David Cameron, the conservatives and the environment. British Politics, 10(2), 204-225.

Čavoški, A. (2015). A post-austerity European Commission: No role for environmental policy? Environmental Politics, 24(3), 501-505.

Delreux, T., and Happaerts, S. (eds) (2016). The evolution of EU environmental policy. In T. Environmental Policy and Politics in the European Union London: Macmillan. (pp. 12-40).

DG Environment. (2020). Enlargement. Retrieved from https://ec.europa.eu/environment/ enlarg/index_en.htm

Downs, A. (1972). Up and down with ecology - The 'issue-attention cycle'. The Public Interest, $28,38-50$.

ENDS Europe. (2013). Green measures blocked by top EU official - Sources (01/03/2013). ENDS Europe. Retrieved from http://www.endseurope.com/30858/green-measures-blocked-bytop-eu-official-sources

European Commission. (2014). Commission Work Programme 2015 : A new start. Brussels: European Commission.

European Commission. (2017). White paper on the future of Europe. Brussels: European Commission. Retrieved from https://ec.europa.eu/commission/sites/beta-political/files/ white_paper_on_the_future_of_europe_en.pdf

European Commission. (2019a). Revised text of the Political Declaration setting out the framework for the future relationship between the European Union and the United Kingdom as agreed at negotiators' level on 17 October 2019, to replace the one published in OJ C 66I of 1. Retrieved from https://ec.europa.eu/commission/sites/beta-political/files/revised_political_declaration.pdf

European Commission. (2019b). The working methods of the von der Leyen Commission: Striving for more at home and in the world. Brussels. Retrieved from https://ec.europa.eu/ commission/presscorner/detail/en/ip_19_6657

European Commission. (2020a). Air Quality - Existing Legislation. Retrieved from https:// ec.europa.eu/environment/air/quality/existing_leg.htm

European Commission. (2020b). Recommendation for a COUNCIL DECISION authorising the opening of negotiations for a new partnership with the United Kingdom of Great Britain and Northern Ireland. Brussels: European Commission. Retrieved from https://eur-lex. europa.eu/legal-content/en/TXT/?uri=CELEX:52020PC0035

Gravey, V., and Jordan, A. (2016). Does the European Union have a reverse gear? Policy dismantling in a hyperconsensual polity. Journal of European Public Policy.

Gravey, V., and Jordan, A. J. (2020). Policy dismantling at EU level: Reaching the limits of 'an ever-closer ecological union'? Public Administration98(2), 349-362.

Gravey, V., and Moore, B. (2019). Full steam ahead or dead in the water? European Union environmental policy after the economic crisis. In C. Burns, S. Sewerin, and P. Tobin (Eds.), The Impact of the Economic Crisis on European Environmental Policy (pp. 19-41). Oxford: Oxford University Press.

Green10. (2019). VdL's 'one in, one out' policy 'incompatible' with climate efforts. Retrieved from https://www.transportenvironment.org/news/vdl's-'one-one-out'-policy-'incompatible'climate-efforts 
Hilson, C. (2018). The impact of Brexit on the environment: Exploring the dynamics of a complex relationship. Transnational Environmental Law, 7(1), 89-113.

Howlett, M., and Cashore, B. (2009). The dependent variable problem in the study of policy change: Understanding policy change as a methodological problem. Journal of Comparative Policy Analysis: Research and Practice, 11(1), 33-46.

Jordan, A., Bauer, M. W., and Green-Pedersen, C. (2013). Policy dismantling. Journal of European Public Policy, 20(5), 795-805.

Jordan, A., Gravey, V., Moore, B., and Reid, C. (2020). Research Paper on the Level Playing Field Commissioned By Friends of the Earth. Norwich: Brexit \& Environment.

Justo-Hanani, R., and Dayan, T. (2020). Environmental policy expansion in the EU: The intriguing case of bioinvasion regulation. Journal of Environmental Policy and Planning, 22(3), 315-327.

Kassim, H., Connolly, S., Dehousse, R., Rozenberg, O., and Bendjaballah, S. (2017). Managing the house: The presidency, agenda control and policy activism in the European Commission. Journal of European Public Policy, 24(5), 653-674.

Knill, C., Steinebach, Y., and Fernández-i-Marín, X. (2020). Hypocrisy as a crisis response? Assessing changes in talk, decisions, and actions of the European Commission in EU environmental policy. Public Administration, 98(2), 363-377.

Lekakis, J. N., and Kousis, M. (2013). Economic crisis, troika and the environment in Greece. South European Society and Politics, 18(3), 305-331.

Löfstedt, R. E. (2007). The 'Plateau-ing' of the European better regulation agenda: An analysis of activities carried out by the Barroso Commission. Journal of Risk Research, 10(4), 423-447.

Milman, O., and Holden, E. (2020, March 27). Trump administration allows companies to break pollution laws during coronavirus pandemic. The Guardian. Retrieved from https:// www.theguardian.com/environment/2020/mar/27/trump-pollution-laws-epa-allowscompanies-pollute-without-penalty-during-coronavirus

Peterson, J. (2017). Juncker's political European Commission and an EU in crisis. Journal of Common Market Studies, 55(2), 349-367.

Pierson, P. (1994). Dismantling the Welfare State? Reagan, Thatcher and the Politics of Retrenchment. Cambridge: Cambridge University Press.

Pollex, J., and Lenschow, A. (2020). Many faces of dismantling: Hiding policy change in nonlegislative acts in EU environmental policy. Journal of European Public Policy, 27(1), 20-40.

Poptcheva, E.-M., and Eatock, D. (2016). The UK's "New Settlement" in the European UnionRenegotiation and Referendum. Brussels: European Parliament.

Reed, M. (2016). 'This loopy idea' an analysis of UKIP's social media discourse in relation to rurality and climate change. Space and Polity, 20(2), 226-241.

Schaffrin, A., Sewerin, S., and Seubert, S. (2014). The innovativeness of national policy portfolios - Climate policy change in Austria, Germany, and the UK. Environmental Politics, 23(5), 860-883.

Sousa, D. J., and Klyza, C. M. G. (2017). "Whither we are tending": Interrogating the retrenchment narrative in U.S. Environmental policy. Political Science Quarterly, 132(3), 467-494.

Steinebach, Y., and Knill, C. (2017). Still an entrepreneur? The changing role of the European Commission in EU environmental policy-making. Journal of European Public Policy, 24(3), 429-446.

Vogel, D. (2003). The hare and the tortoise revisited: The new politics of consumer and environmental regulation in Europe. British Journal of Political Science, 33(04), 557-580.

Wurzel, R. K. W. (2008). Environmental policy: EU actors, leader and laggard states. In J. Hayward (Ed.), Leaderless Europe (pp. 1-26). Oxford: Oxford University Press. 